\title{
Influence of human activities on diversity and abundance of insects in Akure Forest Reserve, Ondo State, Nigeria
}

\author{
Sunday Adeniyi ADEDUNTAN \\ Forestry and Wood Technology Department, Federal University of Technology, Akure. P.M.B. 704 Akure. \\ Nigeria. \\ E-mail:niyi_gbenga@yahoo.co.uk,www.futa.edu.ng
}

\begin{abstract}
This study was carried out to assess the impacts of human activities on insect diversity and abundance in Akure Forest Reserve, Nigeria. Three land uses (fallow land, cocoa agroforest and unlogged forest) were selected for field work within the forest reserve. An hectare block was centrally demarcated in each of the land use types where insects collection and enumeration of trees species took place. 13,578 insects distributed among 30 families belonging to 15 orders were collected and identified and preserved in the insect boxes in the Museum. Within the fallow land, a total of 5,182 insects belonging to 46 families and 8 orders were encountered, while in the cocoa agroforest, 5,884 insects distributed among 50 families and 10 orders and unlogged forest, consist of 2,490 insects distributed into 10 orders and 56 families. The families and order with the highest number of individual insects are Lepidoptera $(4,000)$ and Orthopetera $(1,260)$. These insects are mainly defoliators. The Shannon-weiner diversity index shows that unlogged forest is more diverse than the cocoa agroforest and fallow land. The tree species with the highest frequency per hectare is Cordia platythrsa (Boragiaceae) (6) in fallow land, Theobroma cacao (50) in cocoa agroforestry land Celtis zenkerii (Ulmaceae) in unlogged forest land. A total of 14, 26 and 41 species of tree were identified in the fallow land, cocoa agroforestry land and untouched forest respectively.

(C) 2009 International Formulae Group. All rights reserved.
\end{abstract}

Keywords: Biodiversity, agroforestry, insect defoliators, land uses, fallow land, conservation.

\section{INTRODUCTION}

Forest throughout Nigeria and the rest of tropical countries are diminishing at an alarming rate of $3.5 \%$ (about 350,000-400,000 ha) per annum (Oyebo, 2006) in land coverage over the past 50 years in Nigeria. The natural forests are increasingly being depleted in Nigeria through indiscriminate extraction of economic trees and encroachment for other purposes such as large scale agriculture, urbanization and industrial development. Forest clearance, whether partial or complete, represents a major threat to Arthropod diversity. Deforestation has been attributed to be the aftermath of various activities of man in his daily struggle for survival. Over-exploitation of the existing tropical forest resources and the disappearance of economic and other important hardwood species is a threat to global biodiversity conservation and abundance of insect species and this has become an issue of great current concern today (Sutton and Collins, 1991). Watt et al. (1987) reported that the degree and method of site clearance create a range of tree species diversity from monoculture to species- 
rich mixtures. They further reported that site clearance also affects the amount of ground cover, in terms of plants, leaf litter and dead wood, and the degree of soil compaction that in turn affects the soil environment for important invertebrates such as ants, termites and earthworms. Hill et al. (1995) in their study of effects of selective logging on tropical forest butterflies on Buru, Indonesia, reported that species richness, abundance and evenness of butterflies were all significantly higher in unlogged forest than in forest logged 5 years previously which they attributed to greater vegetation cover at canopy and understory levels which made it to be more shaded below the canopy. It has been noted that species richness and diversity of insect decline with increase in human interference in forest ecosystem (Adeduntan et al., 2005).

There are several approaches to tropical forest management including sustainable management of natural forest, enrichment planting and other techniques where areas of forest are partially cleared before planting, agroforestry methods and the establishment of plantations after complete clearance. Some of the silvicultural options relevant to West and Central Africa are discussed by Lawson (1994).

The impact of plant species diversity on insect diversity and damages caused by insects has been discussed by many authors (Altieri and Schmidt, 1986; Andrew, 1992). Most reports claimed that increase in plant diversity will subsequently lead to an increase in insect diversity and decrease in the risk and extent of attack by insect pest (Altieri and Schmidt, 1986). The view that damage to plants is more likely to occur in monoculture than in mixtures was derived mainly from large number of observation of agricultural and forest crops susceptible to pest attack (Andrew, 1992) and the smaller number of observations in natural ecosystems and artificially created mixtures that show less herbivory (Lowman and Heatwole, 1992). Several studies have considered the possible ecological basis for differences in the abundance and mixed cropping systems
(Kareiva, 1983). Mortality due to natural enemies of insect herbivores is often greater in plant species mixtures (Kareiva, 1983). However, there is evidence from other studies in agro ecosystems that the resource concentration of host plants in plant species mixtures directly affects herbivores because they are more likely to find and remain in area where host plants are concentrated (Kareiva, 1983). This paper presents information concerning the impacts of different land use systems on diversity and abundance of difference group of arthropods, and the damage they caused.

\section{MATERIALS AND METHODS \\ The study areas}

This study was carried out in Akure Forest Reserve, Ondo State, Nigeria (Figures 1 and 2). It covers an area of $69.93 \mathrm{~km}^{2}$. The three land uses selected for the study were present within this reserve. Akure Forest Reserve is managed by the Department of Forestry, Ondo State, Nigeria. The study site is situated on latitude $7^{\circ} 18^{\prime} \mathrm{N}$ and longitude $5^{\circ} 02^{\prime} \mathrm{E}$. A field camp was established at the study site to collate all insects collected and for field observations. The three land uses were adjacent to each other. The period of the fieldwork was eighteen months, beginning from April 2002 to September 2003. The climate is humid tropical with seasonal variation. The mean annual rainfall is about $4000 \mathrm{~mm}$ with double maxima in the months of July and September and a short relatively dry period in August. December through to February constitutes the major dry season while January and February are the driest months with each having less than $30 \mathrm{~mm}$ rainfall (Ola-Adams and Hall, 1987). The relative humidity at 15 hours Greenwich Mean Time (GMT) is highest in the maxima months of July and September (81\%) and lowest in February (44\%). Temperature ranges from about $20.6{ }^{\circ} \mathrm{C}$ to $33.5{ }^{\circ} \mathrm{C}$. The monthly mean temperature is about $27{ }^{\circ} \mathrm{C}$, a condition that is conducive to the development of tropical rainforest (Adeduntan, 2007). 


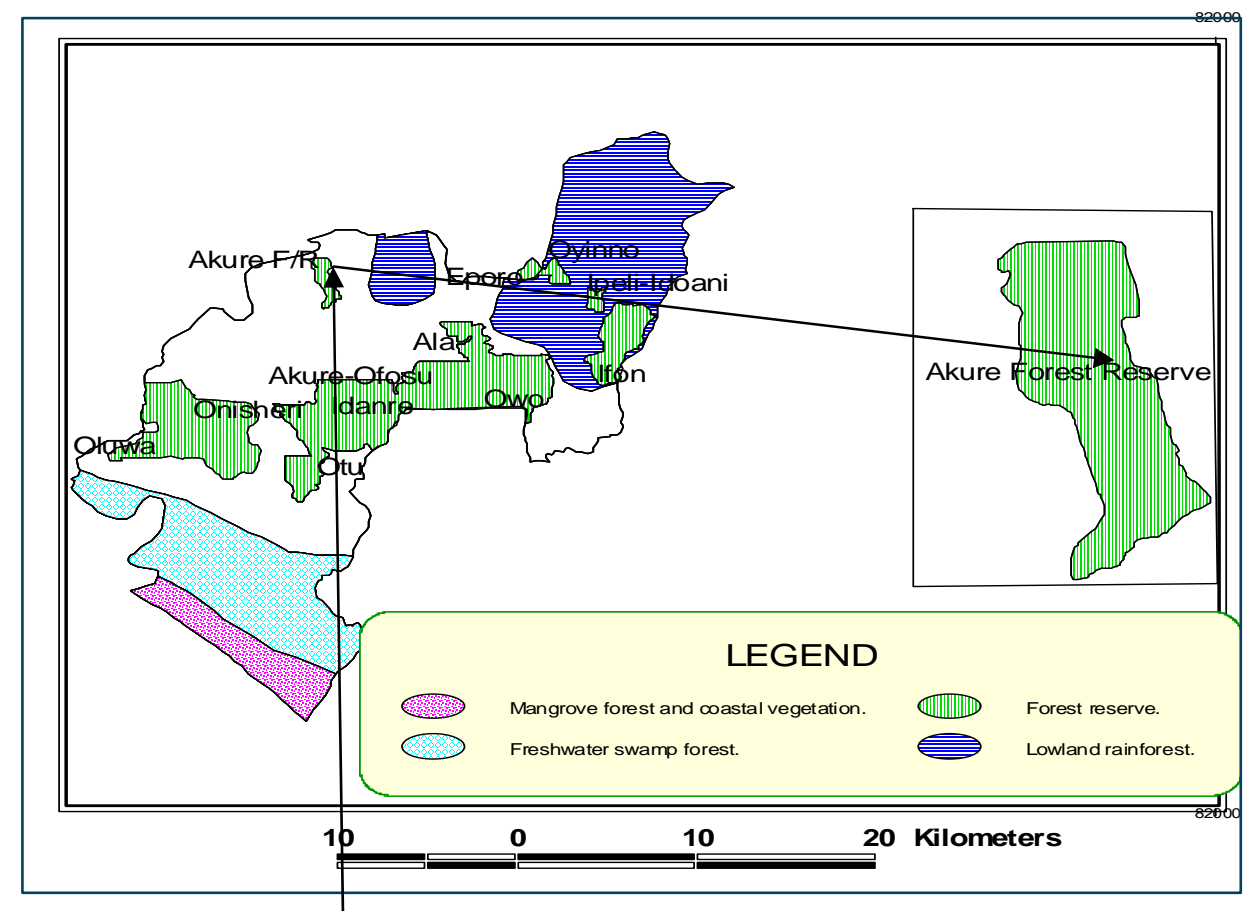

Figure 1: Forest reserves in Ondo State, Nigeria. Source - FORMECU, Abuja, Nigeria (1996).

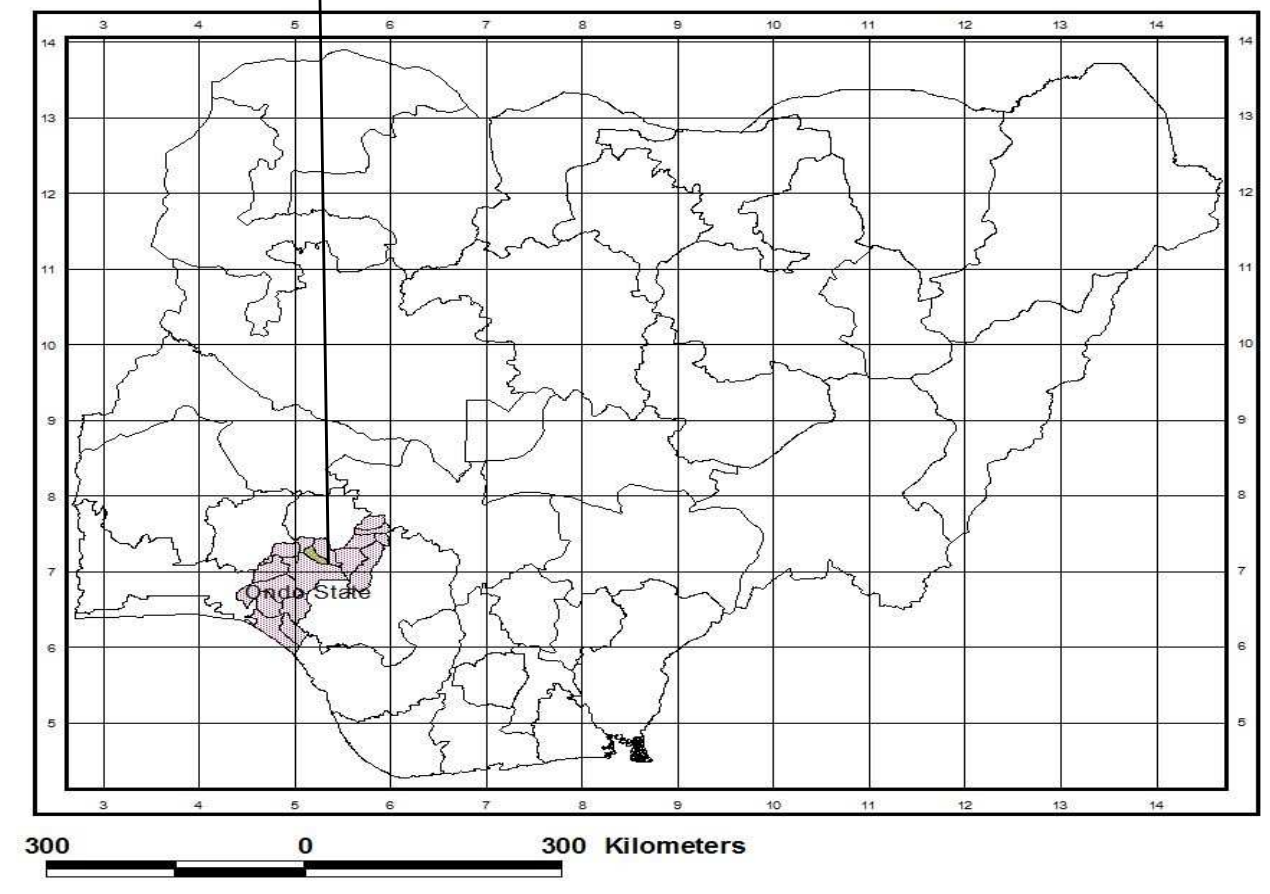

Figure 2: Map of Nigeria showing location of Ondo state. 


\section{Insect collection}

At the centre of each of the selected plots, five trees were tagged. The sampling protocol was targeted at free-living insect herbivores foraging during the daytime on the trees nearer to the tagged sampling point. These include leaf-chewing (e.g. Ledpodeptera, and Orthoptera) and sapsucking insects (Hemiptera). Sampling was carried out monthly for the period of 18 months. During each survey, all the tagged trees were inspected once and the insects were collected alive with hand and sweep nets. An average of at least 30 minutes was spent at each collecting station (Basset 1999 and Adeduntan, 2007).

Hand picking was used to collect crawling insects on the ground and on the trees. An insect Para Taxonomist was employed, as well as field assistants who were trained for some time before the fieldwork commenced. The numbers of mature and young larvae present on each tree at each station during each survey were recorded. All insect species were classified into families and orders. The frequency was obtained to ascertain species abundance / richness and species evenness.

\section{Tree species identification}

The botanical name of trees encountered in the sample plots in each of land use with Dbh of not less than $10 \mathrm{~cm}$ was recorded. In cases where a tree's botanical name was not known, such tree was identified by its common name. Trees that could not be identified, were referred to as 'unknown' and parts of such trees (e.g. leaves, bark, fruits), were collected for identification.

\section{Diversity classification}

All species identified were classified into families and orders. After cross identification with reference material in FRIN (Forestry Research Institute of Nigeria) (1985). The frequencies of occurrence were also obtained to ascertain species abundance/richness (both fauna and floral composition) and species evenness. Plant species going into extinction were identified and recommended for conservation.

\section{Species diversity indices}

According to Dearth and Winterborn (1995), the choice of an index is complicated by the fact that diversity comprises two main components namely species richness and species evenness. Community diversity indices were calculated from mathematical formula that takes into account both species richness and relative abundance of each species in the community. Relative frequency refers to the number of individuals of a given species divided by the total number of individuals of all species found.

\section{$R F=n i / N^{*} 100$}

Where RF is relative frequency, ni is the number of individuals of species $\mathrm{i}$, $\mathrm{N}$ is total number of individuals in the entire population.

The Shannon-Weaver diversity index was used to calculate habitat diversity following Price, (1997): Thies and Tscharntke (1999) and Steffan-Dewenter et al. (2002)

\section{$\mathrm{H}^{1}=-\mathrm{E}$ pi $\ln$ pi}

Where $H^{l}$ is the Shannon diversity index,

$S$ is the total number of species in the habitat,

$p i$ is the relative abundance (Proportion-Number of species in family) i divided by the total number of individual in the habitat and ln is natural logarithm.

Evenness (E) of Magurran, (1988) formulae was used for calculating species evenness.

$$
\mathrm{E}=\boldsymbol{H}^{1} / \mathbf{L n S}
$$

Here $\quad \mathrm{E}=$ Species Evenness

$\mathrm{H}^{\prime}=$ Shannon-Weaver diversity index

$\operatorname{LnS}=$ Natural logarithm of number of species in the habitat,

Evenness ranges from 0-1, with a value of one indicating that all families are equally abundant. 


\section{RESULTS}

\section{Diversity of Insect Herbivores}

Results in Table 1 show the level of insect species diversity, richness and distribution in the site selected for this study. A total of 56 species (15 orders) were encountered in the unlogged forest, 50 species (8 orders) in cocoa agroforest land and 47 species ( 8 orders) in fallow land. In unlogged forest, the insect species with the highest number of individual/ha was Hypolimnas dubius (Lepidoptera;Nymphalinae). The relative frequency in cocoa agroforest land was $4.49 \%$ while in fallow land habitat, it was $0.19 \%$. In cocoa agroforest land, the species with the highest number of individual per ha was Anaphe venata (Lepidoptera; Notodontidae) which is a noxious insect to obeche tree, Triplochition scleroxylon (Sterculiaceae). This insect pest had a relative frequency of $51.22 \%$. It was not encountered in unlogged habitat but its relative frequency in fallow land was also the highest (42.79\%). The abundance of insects in unlogged forest, cocoa agroforest and fallow land are 2490, 5,884 , and 3,184 respectively. The order with the highest number of species in the study area was Lepidoptera with 19 species in unlogged forest, 21 species in cocoa agroforest, and 21 in fallow land. Orthoptera had 9 species in unlogged forest, 9 species in cocoa agroforest and 9 species were present in the fallow land. Likewise, Coleoptera had 11 species in unlogged forest, 7 species in cocoa agroforest, and 3 species in fallow land. These findings suggest that any other land use apart from unlogged forest had higher number of insect species (high species richness), but lower number of individuals (lower species abundance).

The results of the Shannon-Weaver Index reveal that, insect diversity is higher in unlogged forest habitat $\left(\mathrm{H}^{1}=3.622\right)$ than what was obtained in cocoa agroforest $\left(\mathrm{H}^{1}=2.448\right)$ and the fallow land $\left(\mathrm{H}^{1}=2.306\right)$. ShannonWeaver Index of diversity of unlogged forest was one and half times higher $(3.622 / 2.448=$ 1.5) than what was obtained in cocoa agroforestry, while it is almost the same value times higher $(3.622 / 2.306=1.6)$ than what was obtained in fallow land. Shannon-Weaver Index of diversity of cocoa agroforestry land was almost the same value $(2.448 / 2.306=1.1)$ with what was obtainable in fallow land (Table 1).

Tree species diversity, abundance and richness

Forty-one (41) tree species were encountered (species richness) in the unlogged forest with Celtis zenkerii (Ulmaceae) having the highest relative frequency of $14.62 \%$, followed by Drypetes spp. (Mealiaceae) $(12.87 \%)$ and Steculia rinopetala (Sterculiaceae) $(8.77 \%)$. Species with few least distributed are as follows, Dracaena fagara (Avicenniaceae), Enata chlorantha (Annonaceae), Aficilia Africana (Bignoniaceae), Cola milenii (Sterculiaceae), Sterculia tragacantha(Sterculiaceae) and Triplochiton scleroxylon (Ulmaceae) with relative frequency of $0.59 \%$ (Table 3). Shannon-Weaver Diversity Index was calculated to be $\mathrm{H}^{1}=3.215$ (Table 4).

The tree species richness and diversity of cocoa agroforestry forest land is as presented in Table 4. Tree species encountered with the highest frequency in cocoa agroforestry land is Theobroma cacao with relative frequency of $19.05 \%$, followed by $C$. zenkerii with relative frequency of 14.22, followed by Triplochiton scleroxylon (7.94\%). Out of the twenty-six tree species encountered in cocoa agroforestry land seventeen have a relative frequency of $1.59 \%$. Some of such trees species are Albizia zaygia (Sterculiaceae), Cola gigantia (Sterculiaceae), Khaya grandifoliola (Mimosaceae), etc. Shannon-Weaver Diversity Index was calculated for tree species diversity to be $\mathrm{H}^{1}=2.957$.

The species encountered in fallowed land was fourteen, which are distributed among eleven families (Table 4). The species with the highest frequency was Cordia spp., with a relative frequency of $17.14 \%$. This is followed by Triplochition scleroxylon, Celtis zenkerii Milicia excelsa with the same value 
of relative frequency of $11.43 \%$. The least distributed species in fallow land is Albizia zaygia, Ficus exaspirata, Brachystegia enrycoma and Mitragyna stipulosa. ShannonWeaver Diversity Index was calculated to be $\mathrm{H}=2.466$.

The values of Shannon-Weiner Diversity Index as it is presented showed that unlogged forest has the highest community diversity while cocoa agroforest has the lowest. Tree species diversity in the unlogged forest is 1.1 times greater than the tree species diversity in cocoa agroforest, while it is 1.3 times greater than the tree species diversity in the fallow land. Likewise tree species diversity in cocoa agroforest is about 1.2 times greater than tree species diversity in the fallow land.

\section{DISCUSSION}

\section{Diversity of insect herbivores}

Insect species diversity was observed to have higher values in an unlogged forest habitat than in cocoa agroforest and fallow land. Similarly, studies of Hill et al. (1995) demonstrated a reduction in diversity following more extreme forms of forest disturbance. He further observed that species richness; abundance and evenness of butterflies were significantly higher in unlogged forest than in the forest that was logged and abandon five years ago.

The pattern of tree complexity in the three land use could have contributed to the nature of insect species diversity observed in this study which is similar to the findings of Novotany et al. (2006) who reported that the greater the number of tree species in the tropics, the higher the insect diversity. Unlogged forest was observed to have closed canopy with three layers that are very pronounced while cocoa agroforest had some open areas and tree species that scattered over the whole area. This allowed much regeneration of tree wildlings and poles in the open areas, which might have contributed greatly to the enhancement of insect diversity, encountered in study areas.
However, the fallow had very few tree species that are widely spaced. This allowed shrubs and grasses to grow and compete with most of the few tree saplings growing in the habitat, which in turn could greatly affect or reduce insect diversity in the habitat, and encourage the abundance of the few species recorded in study. This observation also agrees with Murdoch et al. (1972) and Southwood et al. (1979) who reported that physical complexity of an environment usually affects arthropod abundance and diversity. It can therefore be deduced that habitat fragmentation and distribution factors contribute to environmental complexity, and this might have affected structural integrity and diversity of the habitat studied as also reported by (Hutcheson and Jones 1999). The lower species diversity of insects in fallow land (Table 2) resulted predominantly from the absence of tree species with higher conservation value because most of economic tree species have been exploited and is in agreement with findings of Thomas (1991).

Greater amount of coarse woody debris that was found in untouched forest habitat than cocoa agroforest land and fallow land could have influenced the insect diversity observed in this study. This observation is supported by Lattin (1993), and Hutcheson and Jones (1999) who noted that terrestrial arthropod diversity including that of Coleoptera could be influenced by coarse woody debris. This was found to be the critical component of structural diversity, and is greater in untouched forest land, the habitat with the highest diversity, followed by cocoa agroforest land.

\footnotetext{
Abundance of different arthropod taxa

The most abundant groups were $A$. venata (Lepidoptera; Notodontidae) with relative frequency of 51.22 and 42.79 in cocoa agroforest and fallow land respectively and ants with relative frequency of 3.70 and 0.07 in unlogged and cocoa agroforest respectively. The abundance and composition of arthropod populations were affected by the land use or level of deforestation.
} 
Table 1: Diversity and relative abundance of insect species in the study habitat.

\begin{tabular}{|c|c|c|c|c|c|c|c|}
\hline \multirow{2}{*}{ Family } & \multirow{2}{*}{ Species } & \multicolumn{2}{|c|}{ Unlogged Forest } & \multicolumn{2}{|c|}{ Cocoa Agroforest } & \multicolumn{2}{|c|}{ Fallow Land } \\
\hline & & Freq./ha & Rel. Freq & Freq./ha & Rel. Freq. & Freq./ha & Rel. Freq. \\
\hline \multirow[t]{14}{*}{ Coleoptera } & Collyris diardi rufitarsis (Klug) & 4 & 0.16 & 8 & 0.14 & 12 & 0.23 \\
\hline & Cicindela tenuipes (Dej.) & 12 & 0.48 & & & & \\
\hline & Catopsilia florealla (Fabricius, 1775). & 78 & 3.13 & 12 & 0.20 & 12 & 0.231 \\
\hline & Cyriopertha glabra (Uzbekistan) & & & 16 & 0.27 & & \\
\hline & Dactylipalpus cicatricosus (Wood and Bright, 1992) & 16 & 0.64 & 28 & 0.48 & & \\
\hline & Euchlora sp. & 20 & 0.80 & 8 & 0.14 & & \\
\hline & Homecerus Pallens F. & 88 & 3.53 & 28 & 0.47 & 60 & 1.16 \\
\hline & Aulacophra sp. & 52 & 2.09 & 60 & 1.02 & 92 & 1.78 \\
\hline & Hypomeces squamosus $\mathrm{F}$. & 8 & 0.32 & & & & \\
\hline & Luxus camerumus (keleb) & 8 & 0.32 & & & & \\
\hline & Cicindelinae & 28 & 1.12 & & & & \\
\hline & Cicindelinae & 4 & 0.16 & & & & \\
\hline & Longicornia & 12 & 0.48 & & & & \\
\hline & Chrysodema jansonii Auroplagiata Dryr. & & & 4 & 0.06 & & \\
\hline \multirow[t]{7}{*}{ Diptera } & Carcelia separata (Rondani) & 34 & 1.37 & 16 & 0.27 & 36 & 0.694 \\
\hline & Deporaus seminiger (Schilsky and Kuster, 1903) & 56 & 2.25 & 52 & 0.89 & 36 & 0.70 \\
\hline & Eristals tenaax (Linnaeus, 1758) & 40 & 1.71 & & & 8 & 0.15 \\
\hline & $\begin{array}{l}\text { Neopleetops } \\
\text { nudinerva (Mesnil, 1956) }\end{array}$ & 8 & 0.32 & & & & \\
\hline & Ptecticus econgatus (Wiedemann, 1830) & 20 & 0.80 & & & & \\
\hline & Tetranychus urticae (Koch) & 4 & 0.16 & 4 & 0.07 & 86 & 1.66 \\
\hline & Sarcophag ybullata (Parker, 1916) & 48 & 1.93 & & & & \\
\hline Hemiptera & Chorisoneura lativitrea (Wlk.) & 48 & 1.93 & 16 & 0.27 & 128 & 2.47 \\
\hline
\end{tabular}


S. A. ADEDUNTAN / Int. J. Biol. Chem. Sci. 3(6): 1320-1335, 2009

\begin{tabular}{|c|c|c|c|c|c|c|c|}
\hline & Anacridium aegytium (Show and Nodder, 1791) & 122 & 4.9 & 320 & 5.44 & 580 & 11.19 \\
\hline & Anoplonemic carvipes $(\mathrm{Fa})$ & 84 & 3.37 & 76 & 1.29 & 52 & 1.00 \\
\hline & Catantrospstylifor (kraws) & 28 & 1.12 & & & 12 & 0.23 \\
\hline & Conocephalus fuscus (Fabricius, 1793) & 40 & 1.61 & 104 & 1.77 & 116 & 2.24 \\
\hline & Euphasiopteryx depleta (Wiedemann) & 28 & 1.12 & 24 & 0.41 & & \\
\hline & Eurema daira (Godart) & 16 & 0.64 & 52 & 0.88 & 124 & 2.39 \\
\hline & Psyra melanonota Stal. (Var.) & 56 & 2.25 & 56 & 0.95 & 76 & 1.47 \\
\hline & Zonocerus variegatus (Linnaeus, 1758) & 2 & 0.08 & & & 144 & 2.78 \\
\hline & Ondotopus sexpuntatus & 38 & 1.53 & 48 & 0.82 & & \\
\hline Homoptera & Macrotristria genus (Walker 1850) & & & & & 88 & 1.70 \\
\hline \multirow[t]{4}{*}{ Hymenoptera } & Anoplius infuscatus (F. 1920) & 12 & 0.48 & & & & \\
\hline & Ancistrocerus parietinus (Linnaeus, 1761) & & & 8 & 0.14 & 4 & 0.08 \\
\hline & Apis mellifera capensis (Eschscholtz 1822) & 68 & 2.32 & 24 & 0.40 & 12 & 0.24 \\
\hline & Megaponera berthoudi (Forel 1890) & 92 & 3.70 & 4 & 0.07 & & \\
\hline \multirow[t]{16}{*}{ Lepidoptera } & Pchypasa subfascia (Walker 1855) & 4 & 0.16 & 8 & 0.14 & & \\
\hline & Acrea lycea $(\mathrm{Gdt})$ & 32 & 1.29 & 24 & 0.41 & 20 & 0.39 \\
\hline & Atherigona pharalis (Seguy, 1938) & & & 12 & 0.20 & 4 & 0.08 \\
\hline & Adela reaumurella (Linnaeus, 1758 ) & 106 & 4.26 & 130 & 2.21 & 32 & 0.62 \\
\hline & Anaphe venata (Butler, 1878) & & & 3014 & 51.22 & 2218 & 42.79 \\
\hline & Anopheles quadrimaculatus (Say) & 20 & 0.80 & & & 60 & 1.16 \\
\hline & Achea serva $\mathrm{F}$. & & & & & 32 & 0.62 \\
\hline & Catopsillia florella (F. D’ Abrera, 1980) & 32 & 1.29 & 58 & 0.99 & & \\
\hline & Carea sp(nr. Nr. Obvia Hmps.,) & 92 & 3.70 & 100 & 1.7 & & \\
\hline & Colias jugurthina (Godart, 1819) & 12 & 0.48 & 40 & 0.68 & 40 & 0.77 \\
\hline & Delia radicum (Linnaeus) & & & 4 & 0.068 & & \\
\hline & Dinumma sp. & 76 & 3.05 & & & 112 & 2.16 \\
\hline & Eronia grandidieri (Mabille, 1877) & & & & & 12 & 0.231 \\
\hline & Psilogramma menephron $\mathrm{Cr}$. & 12 & 0.48 & 12 & 0.20 & 12 & 0.23 \\
\hline & Utethesia lotrix $\mathrm{Cr}$. & & & 4 & 0.07 & 200 & 3.86 \\
\hline & Sictoptera trajiciens Wlk. & & & & & 4 & 0.08 \\
\hline
\end{tabular}


S. A. ADEDUNTAN / Int. J. Biol. Chem. Sci. 3(6): 1320-1335, 2009

\begin{tabular}{|c|c|c|c|c|c|c|c|}
\hline & Spiredonia feducia & 8 & 0.32 & 16 & 0.27 & 6 & 0.12 \\
\hline & Hypolimnas dubuis (Synth, 1880) & 192 & 7.71 & 264 & 4.49 & 10 & 0.19 \\
\hline & Lybthea carinenta (Godman and Salvin, 1884) & 56 & 2.25 & 48 & 0.82 & 36 & 0.70 \\
\hline & Macliplampa scnulteariu & & & & & 16 & 0.31 \\
\hline & Mybthris rhodepe & 4 & 0.16 & 4 & 0.07 & & \\
\hline & Colobura dirce (Linnaeus, 1758 ) & 56 & 2.24 & 128 & 2.18 & & \\
\hline & P. oniparafi & & & & & 12 & 0.231 \\
\hline & Hypermnestra helios (Nickerl, 1846) & 20 & 0.80 & 84 & 1.43 & 8 & 0.15 \\
\hline & Hypermnestra Mnetries 1846 & 8 & 0.32 & 20 & 0.34 & & \\
\hline & Salamis parhassus (Linnaeus, 1758) & 56 & 2.24 & 32 & 0.54 & 8 & 0.154 \\
\hline & Salamis parhesus (Linnaeus, 1758) & 14 & 0.56 & 28 & 0.48 & 16 & 0.31 \\
\hline & Enicosphiloub sp. & 152 & 6.10 & 64 & 1.09 & & \\
\hline & Enicosphiloub sp. & 32 & 1.29 & 32 & 0.54 & & \\
\hline Manteoptera & Galinthia amoena & 8 & 0.32 & 96 & 1.63 & & \\
\hline Neuroptera & Nepheronia Butler 1870 & & & & & 16 & 0.31 \\
\hline \multirow[t]{5}{*}{ Odonata } & Megaloprepus coerulatus (Drury, 1782) & 152 & 6.10 & 316 & 5.37 & 312 & 6.02 \\
\hline & Hagenonyis tritis (walker) & 76 & 3.052 & & & & \\
\hline & Anax strenuus (Hagen, 1867) & & & 152 & 2.58 & 14 & 0.27 \\
\hline & Libellula quadrimaculata (Subsp. Asahinai Schmidt, 1957) & & & 88 & 1.50 & 20 & 0.39 \\
\hline & Phyllogomophus moudi (Frasses) & 96 & 3.86 & 136 & 2.31 & 286 & 5.52 \\
\hline \multirow[t]{2}{*}{ Orthoptera } & Acheta assimilis (Gryllus) & & & 2 & 0.03 & & \\
\hline & Total Abundance & 2498 & 100 & 5884 & 100 & 5184 & 100 \\
\hline
\end{tabular}


Table 2: Community diversity of insect species in the study area.

\begin{tabular}{|l|c|l|l|l|}
\hline \multicolumn{1}{|c|}{ Site } & \multicolumn{1}{|c|}{$\begin{array}{c}\text { Number of } \\
\text { Species }\end{array}$} & $\begin{array}{c}\text { Number of } \\
\text { Trees / Ha }\end{array}$ & H' Index $^{\prime}$ & Evenness (E) \\
\hline Unlogged & 56 & 2490 & 3.622 & 0.8999 \\
\hline Cocoa agroforest & 50 & 5884 & 2.448 & 0.6393 \\
\hline Fallow land & 46 & 5184 & 2.306 & 0.5894 \\
\hline
\end{tabular}

$H^{I}$ is Shannon-Weaver diversity index

The total arthropod diversity and the abundance of Coleoptera Diptera and Hymenoptera (other than ants) were the greatest in the unlogged forest habitat. The abundance of arthropods in the cocoa agroforest plots was surprisingly low but these plots like all forest plots, contained relatively high numbers of Hemiptera, Lepidoptera, Odonata, and Neuroptera, with low number of Diptera.

It was further observed that arthropod number in fallow land was generally low except in Homoptera, Orthoptera. The findings agree with Eggleton et al. (1996) and Watt et al. (1997) who reported that the replacement of intact forest with other land uses will result in the decrease in the abundance of several groups of arthropods. The findings are however, contrary to that of Watt et al. (1997) in Cameroon who reported that the number of termites is markedly higher in disturbed forest.

\section{Relationship between insect abundance and number of tree species}

The trend of diversity observed in Table 1 which showed decrease in order of diversity from unlogged forest, to cocoa agroforest land could be attributed to intensity or level of logging operation that took place in the cocoa agroforest and fallow land. These activities had made these habitats to be devoid of most economic tree species that serve as shelter and source of food for such insect herbivores. Thomas (1991) observed similar results in his studies of habitat use and geographic range of butterflies from the lowland of Coastal Rica. Conversely insect abundance is significantly reduced from fallow land to unlogged forest habitat (Table 1). Population densities of insect species are likely to vary as fallow land regenerates; however, the results of this study agree with earlier report that if fallow land is conserved for 35 - 50 years cycles, there is the possibility of increase in both the diversity and the taxonomic distinctiveness of invertebrate herbivores within the area (Warren, 1985). Less severe disturbance as in the case of cocoa agroforest habitat has negligible effect on insect diversity, which is supported by the findings of Jazen (1970) who studied the insect herbivores and the number of tree species in tropical forests. The results of this study (Table 2) confirm the report of Spitzeu et al. (1997) who reported that moderate levels of logging in Vietnam resulted in higher species richness and diversity of butterflies in the forest gaps, a result that was different from that of Hill et al. (1995) who studied large-scale disturbance. Tree species were positively correlated with insect species (Equation....1), which indicated that an increase in the number of tree species would lead to an increase in the insect diversity. There was high correlation coefficient value $(r=0.889)$ between insect abundance and number of trees present in the sampled areas. The $r^{2}$ was very high $\left(r^{2}=\right.$ 0.790 ) which means that the equation could be used to predict the future insect abundance for the study area and any other similar site (Equation....1). Altieri and Letourneau (1982), and Andrew (1991) reported from their studies that ecosystem structural and plant diversity affect the population load of 
Table 3: Diversity and relative abundance of trees species in the study habitats.

\begin{tabular}{|c|c|c|c|c|c|c|c|}
\hline \multirow[b]{2}{*}{ Family } & \multirow[b]{2}{*}{ Species } & \multicolumn{2}{|c|}{ Unlogged Forest } & \multicolumn{2}{|c|}{ Cocoa Agroforest } & \multicolumn{2}{|c|}{ Fallow Land } \\
\hline & & Freq./hect & pi(RelFreq) & Freq./hect & pi(Rel. Freq.) & Freq./hect & pi(Rel req.) \\
\hline \multirow[t]{4}{*}{ Annonaceae } & Chrysophyllum spp & 4 & 1.17 & 4 & 3.18 & & \\
\hline & Cleistpholis patens (Benth) & 2 & 0.59 & & & & \\
\hline & Enata chlorantha (Oliv) & 2 & 0.59 & & & & \\
\hline & Xylopia aethiopica (Dunal) & 4 & 1.17 & & & & \\
\hline \multirow[b]{2}{*}{ Apocynaceae } & Funtumia elastica (Preuss) & 12 & 3.51 & 2 & 1.59 & & \\
\hline & Hunteria umbelata (Schum) & 10 & 2.92 & & & & \\
\hline \multirow[b]{3}{*}{ Avicenniaceae } & Picralima nitida (Stapf) & 2 & 0.59 & & & & \\
\hline & Rauvolfia vomitoria (Afzel.) & & & 2 & 1.59 & & \\
\hline & Dracaena fagara (Arborea) & 2 & 0.59 & & & & \\
\hline \multirow[b]{2}{*}{ Bignoniaceae } & Aficilia Africana (Baker) & 2 & 0.59 & & & & \\
\hline & Newbouldia laevis (Lee-viss) & & & 2 & 1.59 & & \\
\hline Boragiaceae & Cordia pathytiza (Forst) & 10 & 2.92 & 2 & 1.59 & 12 & 17.14 \\
\hline \multirow[b]{2}{*}{ Capparidaceae } & Brachystegia enrycoma (Harms) & 8 & 2.34 & & & 2 & 2.86 \\
\hline & Erythrophyleum spp (Afzel) & 4 & 1.17 & & & & \\
\hline \multirow[b]{2}{*}{ Ebenaceae } & Buchholzia coriacea (Enyl) & 8 & 2.34 & & & & \\
\hline & Diospyros crassiflora (Hiera) & 4 & 1.17 & 6 & 4.76 & & \\
\hline Euporbiaceae & Bridelia spp (Willd) & 12 & 3.51 & 2 & 1.59 & & \\
\hline \multirow{3}{*}{ Meliaeceae } & Drypetes spp (Hutch) & 44 & 12.87 & & & & \\
\hline & Ricinodendron heudelotii (Bail) & 8 & 2.34 & 6 & 4.77 & 4 & 5.71 \\
\hline & Guarea thompsonii (Sprague and & 4 & 1.17 & 2 & 1.59 & & \\
\hline
\end{tabular}


S. A. ADEDUNTAN / Int. J. Biol. Chem. Sci. 3(6): 1320-1335, 2009

\begin{tabular}{|c|c|c|c|c|c|c|c|}
\hline & Hutch) & & & & & & \\
\hline \multirow{8}{*}{ Mimosaceae } & Khaya grandifoliola (Taylor) & 2 & 0.59 & & & & \\
\hline & Milicia excelsa & & & & & 8 & 11.49 \\
\hline & Pentaclethra macrophlla (Benth) & 4 & 1.17 & & & & \\
\hline & Bosqueia anglensis (Ricalho) & 16 & 4.68 & & & & \\
\hline & Musanga ceropioides (Tedlie) & 8 & 2.34 & 8 & 6.35 & & \\
\hline & Myrianthus arboreus (Beauv) & 8 & 2.34 & 2 & 1.59 & & \\
\hline & Treculia Africana (Deone) & & & 2 & 1.59 & & \\
\hline & Aibizia zygia (Machor) & & & 2 & 1.59 & 2 & 2.86 \\
\hline Moraceae & Ficus exaspirata (Vabl) & 4 & 1.17 & 4 & 3.18 & 2 & 2.86 \\
\hline Myristicaceae & Pycnanthus anglensis (Welw) & 6 & 1.75 & 14 & 11.11 & 4 & 5.71 \\
\hline Olacaceae & Strombosia postulate (Oliv) & 6 & 1.75 & 2 & 1.59 & & \\
\hline \multirow[t]{2}{*}{ Papilionaceae } & Pterocarpus soyauxii (Taub) & 6 & 1.75 & 2 & 1.59 & & \\
\hline & Barteria fistulosa (Mast) & 2 & 0.59 & & & & \\
\hline Rosaceae & Parinari robusta (Olivi) & 4 & 1.17 & & & & \\
\hline \multirow[b]{2}{*}{ Rubiaceae } & Mitragyna stipulosa (Kuntze) & & & & & & \\
\hline & Blighia sapida (Radik) & & & 4 & 3.18 & 2 & 2.86 \\
\hline \multirow[b]{2}{*}{ Rutaceae } & Gmelina arborea (Roxb) & & & & & 6 & 8.57 \\
\hline & Xanthoxylon $s p$ & 6 & 1.75 & 2 & 1.59 & & \\
\hline Sterculiaceae & $\begin{array}{l}\text { Aibizia ferrugininiazygia (Guill and } \\
\text { Perr) }\end{array}$ & & & 2 & 1.59 & & \\
\hline \multirow[t]{4}{*}{ Sterculiaceae } & Aibizia zygia (Machr) & & & 2 & 1.59 & & \\
\hline & Cola millenii (Shum) & 2 & 0.59 & & & & \\
\hline & Mansonia altisima (Chew) & 14 & 4.09 & & & & \\
\hline & Pterygota macrocarpa (Schum) & 2 & 0.59 & & & 2 & 2.86 \\
\hline
\end{tabular}


S. A. ADEDUNTAN / Int. J. Biol. Chem. Sci. 3(6): 1320-1335, 2009

\begin{tabular}{|c|c|c|c|c|c|c|c|}
\hline & Steculia rinopetala (Schum) & 30 & 8.78 & & & & \\
\hline & Sterculia tragacantha (Lindl) & 2 & 0.59 & 6 & 4.77 & & \\
\hline & Terminalia superba (Eng. and Diels) & & & 8 & 6.35 & & \\
\hline \multirow{5}{*}{ Ulmaceae } & Triplochytion scleroxylon (Schum) & 2 & 0.59 & 10 & 7.94 & 8 & 11.43 \\
\hline & Celtis midrip (Engl) & 10 & 2.93 & & & & \\
\hline & Celtis zenkerii (Engl) & 50 & 14.62 & 24 & 19.05 & 8 & 11.43 \\
\hline & Holoptelia grandis ((Hutch) & & & & & 4 & 5.71 \\
\hline & Total Abundance & 342 & 100 & 126 & 100 & 70 & 100 \\
\hline
\end{tabular}

Table 4: Community diversity of tree species in the study area.

\begin{tabular}{lllll}
\hline \multicolumn{1}{c}{ Site } & \multicolumn{1}{c}{$\begin{array}{c}\text { Number of } \\
\text { Species }\end{array}$} & $\begin{array}{c}\text { Number of } \\
\text { Trees / Ha }\end{array}$ & $\mathbf{H}^{\prime}$ Index & Evenness \\
\hline Unlogged & 41 & 342 & 3.215 & 0.8657 \\
Cocoa agroforest & 26 & 126 & 2.957 & 0.8866 \\
Fallow land & 14 & 70 & 2.466 & 0.9294 \\
\hline
\end{tabular}

$H^{\prime}$ is Shannon-Weaver diversity index 
herbivorous insects. Motte (1976) also reported that massive removal of shade trees from coffee agro-ecosystems resulted in outbreaks of coffee leaf miner. Also, there is evidence from other studies in agroecosystems that the species concentration of host plants or species richness directly affects insect herbivores because they are more likely to find and remain in areas where their host plants are concentrated (Wint, 1982). This was actually reflected in this study especially with $A$. venata whose abundance was very high in cocoa agroforest land where the concentration of its host plant $T$. sclerosylon were more.

\section{Conclusions and recommendations}

Land uses has drastic devastating effect on both insect and plant diversity. Reduction of tree species diversity in land use reduces insect diversity but increases insect abundance, with the consequence of increasing insect damage as well as ultimate reduction in quality and quantity of plant food available.

Biological diversity and the diversity of forest dwelling organisms are higher in cocoa agroforestry plantations than non-shade crop or fallow land. Diversity will increase with an increase in both floristic and structural diversity of the shade level.

The studies further found that insect pests of tree species are more associated with trees of disturbed land uses. Pest problems may arise as result of partial or complete clearance of forest trees.

In other to promote biodiversity in cocoa agroforestry (i.e. one of land use systems) in the tropics there must be firm empirical establishment of the value of cocoa agroforestry as a conservation tool. The geographic and taxonomic scope of biodiversity surveys needs to be greatly expanded and conducted in a systematically comparative fashion - comparing cocoa agroforest farms to other agricultural habitats, comparing among different management schemes of cocoa agroforest, with the emphasis on the ability of cocoa agroforest to harbor forest-dependent flora and fauna.

The development of a full range of incentives for farmers to practise cocoa agroforest in a biodiversity friendly manner including fair-trade practices, access to preharvest credit, carbon sequestration credits, and environmental funds based on taxing agrochemical inputs.

\section{REFERENCES}

Adeduntan SA. 2007. Diversity and Abundance of insect herbivores in Akure Forest Reserve, Ondo State, Nigeria. Ph.D Thesis, Federal University of Technology Akure, Nigeria, 138p.

Adeduntan SA, Ofuya TI, Fuwape JA. 2005. Environmental effects of insect herbivores and logging on tree species diversity in Akure Forest Reserve (Aponmu), Nigeria. Applied Tropical of Agriculture, 9(1\&2): 12-18.

Altieri MA, Letourneau DK. 1982. Vegetation management and biological control in agrosystems. Crop Production, 1: 409430.

Altieri MA, Schmidt LL. 1986. The dynamics of colonizing arthropod communities at the interface of abandoned, organic and commercial apple orchards and adjacent woodland habitats. Agriculture Ecosystems and Environment, 16: 29-43.

Andrew DA. 1991. Population dynamics of insect herbivores in simple and diverse habitats. Ecology, 71: 1006-1017.

Basset Y. 1999. Diversity and abundance of insect herbivores foraging seedlings in a rainforest in Guyana. Ecological Entomology, 24: 245-259.

Dearth RC, Winterborn MJ. 1995. Diversity Patterns in Stream invertebrate communities. Ecology, 76: 1446-1460. 
Eggleton P, Bifnell DE, Sands WA, Mawdsley NA, Lawaton JH, Bignell NC. 1996. The diversity, abundance and biomass of termites under different levels of disturbance in the Mbalmayo Forest Reserve, southern Cameroon. Philosophical Transaction of the Royal Society of London Series of London Series B-Biological Science, 351: 51-68.

FRIN (Forestry Research Institute of Nigeria). 1985. High forest investigations in Nigeria - A report on the state of work by S. P. K. Britwum. Technical Note No. 47, 64p.

Formecu. 1996. Digital files of vegetation and land use Map of Nigeria. Projection UTM. Zones 31, 32, 33.

Hill JK, Harmer KC, Lace LA, Banham WMT. 1995. Effects of selective logging on tropical forest butterflies on Buru, Indonesia. Journal of Applied Ecology, 32: 754-760.

Hutcheson J, Jones D. 1999. Spartial variability of insect communicaties in a homogenous system: Measuring biodiversity using Malaise trapped beetles in a Pinus radiate plantation in New Zealand. For Ecological Management, 118: 93-105.

Janzen DH. 1970. Herbivores and the number of tree species in tropical forests. America Naturalist, 104: 501-528.

Kareiva P. 1983. Infuence of vegetation textureon herbivore population: resource concentration and herbivore movement. In Variable Plants and Herbivores in Natural and Managed Systems, Denno RF, McClure MS (eds). Academic Press: New York; 259-289.

Lattin JD. 1993. Athropod diversity and conservation in old-growth northwest forests. American Zoology, 33: 578-587.

Lawson GL. 1994. Indigenous trees in West African forest plantations. The need for domestication by clonal techniques. In
Tropical Trees: the Potential for Domestication and the Rebuilding of Forest Resources, Leakey RRB, Newton AC (eds). HMSO: London; 112-123.

Lowman MD, Heatwole H. 1992. Spatial and temporal variability in defoliation of Australia eucalyptus. Ecology, 73: 129142.

Magurran A. 1988. Ecological Diversity and its Measurement. Chapman \& Hall: London.

Murdoch WW, Evan WC, Peterson CH. 1972. Diversity and pattern in plant and insect. Ecology, 53: 819-829.

Motte G. 1976. Investifations sobre la biologia yel connel del 'minador' del café (Leucoptera Coffeclla Guer.) en café de sol (coffea arabica var. caturra) en Cuba. Academia de Ciecias de Cuba (INIFAT), pp 40-45.

Novotany V, Drozed P, Miller SE, Kulfa M, Janda M, Basset Y, Weiblen G. 2006. Why are there so many species of herbivorous insects in tropical rainforests? Science Express, published online. 10.1126/science. 1129237.

Ola-Adams BA, Hall JB. 1987. Soil-plant relation in a natural inviolate plot at Akure, Nigeria. Journal of Tropical Ecology, 3: 57-74.

Oyebo MA. 2006. History of Forest Management in Nigeria from $19^{\text {th }}$ Century to Date. In Imparatives of Space Technology for Sustainable Forest Management, Ayobami TS (ed). Proceedings of an International Stakeholders' Workshop Sponsored by National Space Research and Development Agency Held in Abuja, Nigeria Between $27^{\text {th }}$ and $28^{\text {th }}$ March 2006, pp.1-14.

Price PW. 1997. Organization of plantarthropod association in simple and diverse habitats: the fauna of collars 
(Brassica olerds, Brassica oleraceae). Ecol. Monograph, 43: 95-124.

Steffan-Dewenter I, Munzenberg U, Burger C, Thies C, Tschorntke T. 2002. Swcale dependent effects of landscape context on three pollinator guilds. Ecology, 83: 1421-1432.

Spitzeu K, Jaro J, Havelka J, Leps J. 1997. Effects of small-scale disturbance on butterfly communities of an Indochna montane rainforest. Biological Conservation, 80: 9-15.

Southwood TRE, Brown VK, Reader PM. 1979. The relationships of plant and Insect diversities in succession. Biological Journal of the Linnean Society, 12: 327-348.

Sutton SL, Collins NM. 1991. Insects and tropical forest conservation. In The Conservation of Insects and their Habitats, Collins NM, Thomas JA (eds). Academic Press: New York.
Theis C, Tscharntke T. 1999. Landscape structure and biological control in groeco systems. Science, 285: 893-895.

Thomas JA. 1991. Habitat use and geographic range of butterflies from the lowland of Coastal Rica, Biological. Biological Conservation, 55: 269-281.

Watt AD, Stork NE, Eggleton P, Strivastava D, Bignell DE. 1987. Impact of forest loss and regeneration on insect abundance and diversity. In Forests and insects, Watt A.D, Stork NE, Hunter MD (eds). Chapman and Hall: London; 271284.

Warren MS. 1985. The influence of shade on butterfly numbers in woodland rides, with special reference to the wood white Leptidea sinapis. Biological Conservation, 33: 144-164.

Wint GRW. 1982. Leaf damage in tropical forest canopies. In Tropical Rain Forest, Chadwick (ed). Blackwell Scientific Publications: Oxford. 